\title{
Determining Drivers of Destination Attractiveness: The Case of Nature-Based Tourism of Bangladesh
}

\author{
Saiful Islam ${ }^{1}$, Md. Kaium Hossain ${ }^{2} \&$ Mahboob Elahi Noor ${ }^{3}$ \\ ${ }^{1}$ Lecturer, Department of International Business, University of Dhaka, Bangladesh \\ ${ }^{2}$ Assistant Professor, School of Business and Economics, United International University, Bangladesh \\ ${ }^{3}$ Department of International Business, University of Dhaka, Bangladesh \\ Correspondence: Saiful Islam, Lecturer, Department of International Business, University of Dhaka, Bangladesh. \\ Tel: 880-1911-463-733. E-mail: saifulib@du.ac.bd
}

Received: March 19, 2017 Accepted: May 2, $2017 \quad$ Online Published: May 29, 2017

doi:10.5539/ijms.v9n3p10 URL: http://doi.org/10.5539/ijms.v9n3p10

\begin{abstract}
The purpose of this study is to identify the most important drivers for developing destination competitiveness of Bangladesh nature-based tourism by evaluating tourists' perception. A nationwide structured questionnaire survey of total 432 Bangladeshi tourists is carried out by dividing the whole country into two parts for equal representation. Based on this data, a profile of the tourists is constructed before ranking of attributes from most important to least important on a five-point Likert scale. An Exploratory Factor Analysis (EFA) has been conducted finally to identify the most important factors from 24 selected attributes related to nature-based tourism of Bangladesh. The key findings indicate that seven attributes are more important to respondents than others as all these has average importance value more than 4 out of 5 while only two is least important. From the EFA of these attributes, supported by a parallel analysis, four major factors are extracted namely, tourism infrastructure; historical and cultural attractors; natural attractors; and communication facilities and lifestyle similarities. Thus, this study will help both policy makers to develop long term destination policy focusing on natural attractors and service providers to customize their services according to tourists' expectation. Consequently, this paper conceptualizes the importance of focusing on specific sectors of tourism and the way of developing competitiveness of nature-based tourism of Bangladesh. However further studies can be conducted to match tourists' evaluation of attributes on importance and performance and/or evaluating same perception from service providers rather than tourists.
\end{abstract}

Keywords: Bangladesh tourism, destination attractiveness, destination competitiveness, destination drivers, nature-based tourism

\section{Introduction}

Tourism is one of the fastest-growing industries in the world and the main source of foreign income for a significant number of developing countries (Cucculelli \& Goffi, 2015). Therefore, identification and analysis of factors that are important for designing tourism services and managing destination has been the subject of much attention in related academic literatures, and has made a significant contribution to a greater understanding of tourist behavior (Beerli \& Martin, 2004; Enright \& Newton, 2004; Madhavan \& Rastogi, 2011; Mohsin \& Ryan 2004). In this regard, there are close relations among tourist's expectation about destination attributes, nature of destination management (Crouch, 2011; Dwyer, Cvelbar, Mihalič, \& Koman, 2014), positive image of the destination (Crompton, 1979; Gartner, 2007; Pike, 2002) and destination competitiveness (Armenski, Dwyer, \& Pavluković, 2017; Cucculelli \& Goffi, 2015; Dwyer, Armenski, Cvelbar, Dragićević, \& Mihalic, 2015). Successful identification of attributes is thus significant to specific tourism sector for designing tourism management in a more appropriate way and in turn which will enhance destination competitiveness in a given location.

However, as destination competitiveness attributes are location specific, a number of previous studies contribute to develop theoretical models to explain destination image and competitiveness (Cucculelli \& Goffi, 2015). Crouch \& Ritchie (1999) developed first conceptual model based on Porter's (1990) well-known framework of the "diamond of national competitiveness". Such revolutionary model is then refined in Ritchie \& Crouch (2000, 
2003) and Crouch (2011). Later a number of theoretical models have also been developed (De Keyser \& Vanhove, 1994; Dwyer, Livaic, \& Mellor, 2003; Hassan, 2000; Heath, 2003), as well as to analyze the competitive positions of tourism destinations (Dwyer et al., 2003; Enright \& Newton, 2004; Gomezelj \& Mihalic, 2008; Sirse \& Mihalic, 1999). All of these models identified most relevant factors, including attributes within it, for developing destination competitiveness through extraction from a long list of tourism items or attributes. In this regard, a number of approaches (EFA, IPA, AHP, ranking of attributes etc.) are used in the methods.

Moreover, destination specific attributes and facilities might be important in the selection of a destination over others. Destination specific aspects are climate, recreation facilities, sightseeing location, and information about the destination (Madhavan \& Rastogi, 2011; McIntosh \& Goeldner, 1990). Besides, Hueng, Qu, \& Chu (2001) has suggested the factors of tourism development like, quality of road, private and public transport facilities and telecommunication for choosing tourism destination. Alhemoud \& Armstrong (1996) also found tourists consider societal determinants while making a travel (Hueng et al., 2001). Additionally, Mohsin \& Ryan (2004) have found a number of socio-demographic factors that tourists perceive significantly before choosing a tourism destination like income level, age, occupational composition and marital status.

However, application of these models and assessment of importance factors are still insignificant in specific tourism sectors like, leisure tourism, medical tourism, nature-based tourism, sports tourism, culinary tourism, education tourism and religious tourism, etc. In this connection, Balmford et al. (2009) found that, though the nature-based tourism is growing rapidly all over the world, two major economic countries USA and Japan are facing difficulty in attracting tourists in this industry. Few reports (Laarman \& Gregersen, 1996; Priskin, 2001; Tisdell \& Wilson, 2012) inferred tourists have been shifting their natural tourism destinations to Europe, Middle-East and South-East Asian countries. It is also found from the researches that poorer countries typically had increasing numbers of nature based tourism visits, with median standardized rates of growth in total visit numbers.

Bangladesh having various kinds of natural variations e.g., hilly areas, sea beaches, mangrove forest and many historical places, has a huge potential in the scenario of world tourism (Ahmed, Azam, \& Bose, 2010). It is located in South Asia and bordered by India (West, North and north east), Myanmar (South East), and Bay of Bengal (on the South). As a small riverine country, Bangladesh possesses tremendous natural and cultural resources for the development of tourism industries. Specifically, it has two undisputed heritages, the Sundarbans (world largest natural mangrove forest) and Cox's Bazaar sea beach (world's longest unbroken sea beach. Apart from these, other historical, cultural and archeological tourist sites have been developed in certain pocket throughout the country. All these indicate the potentiality of developing nature-based destination competitiveness for Bangladesh. Hence, determining the most important drivers for nature-based tourism competitiveness of Bangladesh would be top priority.

Therefore, this study, as an applied research, is intended to develop an idea of factors important to nature-based tourism of Bangladesh to maintain destination competitiveness in the context of a changing tourism environment To complete this aim, several objectives of the paper are, first, exploring current status of nature-based inbound tourists of Bangladesh, second, ranking the selected relevant attributes of tourism from most important to least important, third, identifying the most important factors in designing nature-based tourism of Bangladesh through Exploratory Factor Analysis (EFA) and fourth, suggesting policies to improve tourism services and to attract more tourist in nature-based tourism of Bangladesh.

The reminder of this paper is organized as follows. Section 2 reviews the literature on tourism destination competitiveness, destination image, perception of tourist in selection of a destination and attributes significantly related to developing nature based tourism destination competitiveness. The methodology of the study is proposed and described in section 3. Section 4 provides the results and discussion on descriptive statistical analysis, ranking of the attributes and exploratory factor analysis from the collected data on different variables. Conclusions and decision implications are presented in section 5.

\section{Literature Review}

Destination competitiveness literatures reveal that diversified managerial initiatives are important to increase destination competitiveness (Ritchie \& Crouch, 2003). At this point, developing more tourist friendly destination services requires strategies in which certain features are specific to a tourism industry at a particular time as well as level of destination development (Dwyer, Edwards, Mistilis, Roman, \& Scott, 2009). Designing such strategies should thus emphasis developing a good destination image on which tourist preference of important criterion would be reflected. A list of several attributes donates to measure this destination image (Sonmez, 2002). Moreover, based on previous studies, there exists a general consensus about the significance of the role 
played by image is the process of decision making, and, by extension, choice of tourists (Baloglu \& McCleary, 1999; Chen, 1999; Goodrich, 1978; Hunt, 1975; Milman \& Pizam, 1995).

In addition to the decision-making process and choice, tourist perception about a destination is also important, which emphasized on a set of attributes formed based on the sources of information. As a persuading factor, information sources along with a number of other factors are exposed to determine certain destinations (Fakeye \& Crompton, 1991; Gartner, 1993; Mansfeld, 1992; Um \& Crompton, 1990). In the connection with information sources, a tourist set some important factors back of his mind before travelling to any tourist spot which commonly recognized as destination image, "the sum of beliefs, ideas, and impressions that a person has of a destination" (Crompton, 1979). Some researchers relate the importance of proper image development to the overall success of a destination in tourism (Chen, 1999; Crompton, 1979; Dadgostar \& Isotalo, 1992; Gartner, 2007; Hunt, 1975).

A review of 142 papers in the destination image literature from the period 1973-2000 was undertaken by Pike (2002) where a wide range of interests is found. These were: the effect of visitation (15), segmentation (12), image differences between different groups (8), affect (6), the effect of distance from the destination (6), intermediaries (6), induced images (5), top of mind awareness decision sets (5), culture (4), temporal image change (3), negative images (3), the effect of familiarity with the destination (3), less developed destinations (3), length of stay (LOS) (3), event impact (2), scale validity (2), value (2), image formation (2), and single papers interested in primary image, rural tourism, weather, traveler confidence, impulse decision-making, travel context, barriers to positioning, personal holiday photos, motivation, experience, stereotypes, budget travelers, intent to visit and Destination Marketing Organization (DMO) policy.

On the other hand, some researchers emphasized on developing destination competitiveness model in which they identified number of factors and attributes within it that are important to develop a good destination image and competitiveness. Crouch \& Ritchie (1999) began to study the nature and structure of destination competitiveness in 1992 and through a series of extension in Crouch (2011) they identified 36 destination competitiveness attributes into five main groups named core resources and attractors; supporting factors and resources; destination policy, planning and development, destination management, qualifying and amplifying determinants.

Furthermore, Dwyer \& Kim (2003) and Dwyer, Mellor, Livaic, Edwards, \& Kim (2004) also undertook to contribute to the development of a general model of destination competitiveness. Through a series of development, Dwyer et al. (2014) extracted 55 indicators from 135 initial indicators through factor solution analyses using Quartimax rotation. These indicators are categorized into six main factors namely, macro environment, business environment, general infrastructure, endowed resources, tourism infrastructure and destination management, in which management should emphases to develop good destination image to tourists. Other than these, the WEF has ranked the competitive performance of 124 countries of a Travel \& Tourism Competitiveness Index (TTCI) (WEF, 2007). It suggests that this "cross-country analysis of the drivers of competitiveness in travel and tourism provides useful comparative information for making business decisions and additional value to governments wishing to improve their travel and tourism environments" (WEF, 2007).

However, some studies also conducted to identify individually what tourist perceive more important when they select a destination. Beerli \& Martin (2004) classified such attributes into nine dimensions namely, natural resources; natural environment; tourist leisure and recreation; general infrastructure; cultural and historical attractions; social environment; tourist infrastructure; political and economic factors; and atmosphere of the destination which consists of the factors like, family oriented destination, reputation of the place and pleasant of the destination. Tourists' destination choice is reasonably guided by the leisure time and travelling cost also (Goodrich, 1978). Cohen \& Avieli (2004) identified three major areas of budgeting costs that tourists consider when select a destination- transportation cost, accommodation cost, and cost for foods.

Regardless the type of tourist destinations few attributes are common which are associated directly with the nature of ability to create satisfaction level of visitors such as climate, safety and security, good accommodation, relaxation of vacation and reasonable prices (Alegre \& Cladera, 2009; Shih, 1986). The intensity of motivation for making trips is highly related to the choice of destinations. A large number of people are making travel primarily considering the food-related reasons. Desire to eating a typical food, eating outside home and drinking beverages are the important motivations for making trip along with few common motivational factors such as sightseeing, meeting friends, relatives and partners (Hall \& Sharples, 2003). These motivational factors also differ significantly among the tourists according to their age, income level and spiritual belief (Cañizares \& Canalejo, 2015).

Measuring tourist destination competitiveness and determining factors to be considered for further developing 
destination and tourism services, previous studies might be major source of information. In the study of Cucculelli \& Goffi (2015), they found that, the majority of studies look at competitiveness for a single country or a group of countries (e.g., Ahmed \& Khron, 1990; Bahar \& Kozak, 2007; Dwyer et al., 2003, 2004, 2012; Gomezelj \& Mihalic, 2008; Gooroochum \& Sugiyarto, 2005; Haahti, 1986; Haahti \& Yavas, 1983; Kaynak \& Marandu, 2007; Kim \& Dwyer, 2003; Kozak \& Rimmington, 1999; Lee \& Chen, 2010; Mazanec, Wober \& Zins, 2007; Miller, Henthorne, \& George, 2008; Sirse \& Mihalic, 1999; Zhang \& Jensen, 2007). Other empirical studies concentrate on islands (Croes, 2010; Mechinda et al., 2010), big cities (Enright \& Newton, 2004, 2005; Minghetti \& Montaguti, 2010), particular types of destinations (Botha, Crompton, \& Kim, 1999; D'Hautserre, 2000; Lee \& King, 2009), famous resort destinations (Kozak, 2002), and regions/provinces (Cracolici \& Nijkamp, 2008; Faulkner, Opperman, \& Fredline, 1999; Pestana et al., 2011; Zhang et al., 2011). Besides, little such study had been conducted on the destination- Bangladesh.

However, few distinctive studies have been incorporated by using the factor analysis technique in domestic tourism industry of Bangladesh emphasizing on specific tourism destination (Akter \& Hamid, 2013; Hossain, Quaddus, \& Shanka 2011). Tourism managers get a helpful direction by understanding and identifying the attributes considered by the tourists and their satisfaction influenced by these attributes for taking effective strategies to attract tourist in a particular destination. However, these studies emphasized on measuring tourists' satisfaction rather than identifying drivers, those are important for tourism destination competitiveness. Moreover, little literature support is evident for developing nature-based tourism of Bangladesh, as it has huge potentiality in nature based tourism.

World Travel and Tourism Council (WTTC) has recognized the tourism industry of Bangladesh as much promising industry focusing on the few nature-based tourism sites. Sundarbans, Cox's Bazar, Saint Martin, Rangamati and Bandarban are given the priority by this apex global tourism organization which also consist the domestic nature-based tourism industry of Bangladesh. According to the WTTC report, the direct contribution of tourism and travel industry to GDP of Bangladesh was 2.4 percent in 2015. The report also anticipated that the direct contribution of travel and tourism will be increased by 5.3 percent in 2016. In addition to growing contribution in GDP, the report warns for the infrastructure development of this industry. But such promising and beautiful tourist's sites of Bangladesh cannot attract the foreign visitors whereas only 1.7 percent of total travel and tourism spending is generated by the foreign visitors and 98.3 percent of tourism spending is incurred by the domestic visitors. Thus, this study would be really a good addition to the development of Bangladesh nature-based tourism by adding relevant important attributes offered in previous studies.

\section{Methodology}

To identify the basic factors that attract more tourists in nature-based tourism of Bangladesh, this study adopts a quantitative approach of investigation. Quantitative research is a way of testing objective theories by examining the relationship among variables which are measured and analyzed using statistical procedures (Creswell, 2008). Research adopting this approach can offer more reliability, causality and ability to generalize (Bryman, 2001) and have the advantage of dealing with large number of samples within a relatively shorter period (Berg, 2001). However, this approach of investigation is not without its shortcomings (Reaz, 2006). The study is also descriptive in nature. It considers the attributes related to nature-based tourism of Bangladesh which is adopted by reviewing various determinants of the key tourism destination competitiveness (TDC) models (Hanafiah, Hemdi, \& Ahmad, 2016).

Tourism Destination Competitiveness (TDC) models developed by previous studies (Croes \& Kubickova, 2013; Crouch \& Ritchie, 1999; Dwyer \& Kim, 2003; Gooroochurn \& Sugiyarto, 2005; Porter, 1990; World Economic Forum, 2007) and respective updates of these models are reviewed to determine items to be used in survey questionnaire. As mentioned by Gomezelj \& Mihalic (2008), there is no single set of competitiveness indicators that applies to all destinations at all times (Dwyer et al., 2004), 24 items have been selected to be used in the questionnaire. These items are constructed on the basis of adaptability to local nature-based tourism of Bangladesh.

Furthermore, the survey instrument consists of two parts. The first part consists of demographic profiling of the respondents. In this part, basic demographic information of the respondents along with recent tourism experience and intention to visit is measured. On the other hand, the second part of the survey questionnaire adopts those 24 action items that have been selected to determine important drivers to the competitiveness of Bangladesh nature-based tourism. Such a technique is similar to previous studies of same field adapted to supply side of tourism services, Destination Management Organizations (DMO) (Armenski, Dwyer, \& Pavluković, 2017; Dwyer et al., 2009; Dwyer et al., 2012; Dwyer et al., 2014). 
Moreover, based on their importance in increasing the destination competitiveness, each of these 24 items is evaluated by a nature-based tourist group on a 5-point Likert-type scale where the two extremes of the scale, 1 indicated as the "Not at all important" and 5 indicated "Extremely important" items. Questionnaires offer a method of conducting a survey where all respondents are asked exactly the same questions in the same circumstance (Easterby-Smith, Thorpe, \& Lowe, 1991, 1999; Li, Kinman, Duan, \& Edwards, 2000; Merriam, 1988; Payne, 1980). The survey ensures reliability by asking the same questions to all respondents and eliminates unreliability by providing standardize stimuli to all respondents (Hossain, Siddique, \& Islam, 2015). These benefits are exactly why this study has undertaken a questionnaire survey.

A convenience sampling approach was used in the research. Questionnaires are distributed during the four research months of September to December 2016 to the potential tourists who have been planning to visit a nature-based tourism destination of Bangladesh or ready to visit again. Data has been collected through a self-administrated structured questionnaire by trained surveyors who have been taught to collect data by physically questioning and assisting respondents. As nature-based tourism of Bangladesh is largely depended on two locations- Cox's Bazar and Sylhet, respondents are selected on the ground that they have an interest to visit any of these two locations or similar to that. The population of the Bangladesh has been divided into 2 parts and 250 respondents have been targeted from each part for the study. Such a classification and then collection of data helps to generate a representative response from overall populations. Among the questionnaire circulated, 423 returned as useable for the further analysis.

The data collected has been analyzed using Exploratory Factor Analysis (EFA). The goal of EFA is to identify the underlying relationships between measured variables (Hair et al., 2010). Moreover, EFA is primarily an exploratory technique because it limits control over variables loading on latent factor (Armenski, Dwyer, \& Pavluković, 2017, Bentler \& Bonett, 1980). Before conducting the EFA, some descriptive statistics are determined. In the process the reliability of the measures is tested using both the Kaiser-Meyer-Olkin (KMO) measure of sampling adequacy (MSA) and Bartlett's test of sphericity. Furthermore, to test the reliability and internal consistency of the importance scores, the reliability of data checked using Cronbach's alpha value. Parallel analysis is also performed in addition to the factor analysis to retain exact number of factors for successful completion of EFA. In addition to all these, the 24 action items selected for this study is ranked according to their mean value of importance which would be a great insight for further decision making. For these statistical analyses, Statistical Package for the Social Science (SPSS) version 21.0 is used.

\section{Results and Discussion}

The survey questionnaire used in the study includes two major proportions- basic demographic information of the respondents and measurement of the items that respondents feel important in a tourism destination. The most important group of items from this list would be selected when policy makers are going to design more attractive tourism services. To determine such in-depth findings, this study not only explores the important factors from a list of items through exploratory factor analysis, but also formulates a rank of these items based on their overall attractiveness measure by respondent's opinion in a 5 point Likert scale. The following section of the paper includes this ranking of items followed by the findings of EFA and preceded by the major demographic information of respondents.

In nature-based tourism, the demographic and socio economic conditions play a crucial role in determining the respondent's choice of a tourist destination. The survey findings on respondents' demographic and socioeconomic factors are described in the table 1. From the table 1, it's visible that most of the respondents are male (71.2\%) compared to the number of female $(28.8 \%)$ where their age structure shows that large portion of the total respondent are aged between 18-34 years (72.3\%) compared to the second largest respondents group aged between $35-59$ years (24.4\%). Such a nature implies that people between 18 to 34 years are at their youth and love to explore more natural beauties and adventure within the nation. People aged between 35 to 59 is comparatively more matured and find scope for being relaxed through natural tourist destination for relaxation from workaholic life. Majority of the respondents are students in nature (32.6\%) closely followed by respondents involve in service $(29.1 \%)$ and business (19.9\%).

Moreover, in terms of educational qualification, majority has a bachelors/honors degree $(29.9 \%)$ followed by Higher Secondary School Certificate degree (26.1\%) and Master's degree (25.5\%) which indicates that respondent on average are educated and it could be important when making decisions regarding destination choice. More than 50 percent respondent has a monthly family income between 21 thousands and 50 thousands Bangladeshi taka (BDT). The rest portion of respondent has an income of BDT 4,000-20,000 (30.1\%) and more than BDT 50,000 (16.4\%). Vacation/ holiday $(30.50 \%)$ is the main motivation to visit the tourist spot for the 
respondents followed by Visiting friends/ relatives $(28.52 \%)$ and sightseeing $(23.59 \%)$. In addition to these, more than half of the respondents $(59.80 \%)$ made 3 travels or less than that in last three years, whereas $40.20 \%$ respondents made four travels or more than that. Moreover, in the travel, respondents were not interested to stay more than 4 days (73.1\%). Friends/ relatives/ business associates $(64.9 \%)$ is the main sources of information to know about any tourist destination whereas media (25.8\%) played second important sources of information for the surveyed respondents.

Table 1. The demographic and socioeconomic factors of respondents

\begin{tabular}{|c|c|}
\hline Particulars & Percentage \\
\hline \multicolumn{2}{|l|}{ Gender } \\
\hline Male & $71.2 \%$ \\
\hline Female & $28.8 \%$ \\
\hline \multicolumn{2}{|l|}{ Age } \\
\hline $11-17$ & $2.1 \%$ \\
\hline $18-34$ & $72.3 \%$ \\
\hline $35-59$ & $24.4 \%$ \\
\hline $60+$ & $1.2 \%$ \\
\hline \multicolumn{2}{|l|}{ Occupation } \\
\hline Service & $29.1 \%$ \\
\hline Business & $19.9 \%$ \\
\hline Housewife & $10.9 \%$ \\
\hline Student & $32.6 \%$ \\
\hline Others & $7.6 \%$ \\
\hline \multicolumn{2}{|l|}{ Educational Qualification } \\
\hline $\mathrm{SSC}$ & $10.9 \%$ \\
\hline $\mathrm{HSC}$ & $26.1 \%$ \\
\hline Bachelors/Honors & $29.9 \%$ \\
\hline Masters & $25.6 \%$ \\
\hline Others & $7.6 \%$ \\
\hline \multicolumn{2}{|l|}{ Monthly average family Income } \\
\hline $4,000-20,000$ & $30.1 \%$ \\
\hline $21,000-50,000$ & $53.5 \%$ \\
\hline $51,000+$ & $16.4 \%$ \\
\hline \multicolumn{2}{|l|}{ Motivation for Visit } \\
\hline Visiting friends/ relatives & $28.52 \%$ \\
\hline Sightseeing & $23.59 \%$ \\
\hline Vacation/Holiday & $30.50 \%$ \\
\hline Business/Convention & $5.32 \%$ \\
\hline Learning/Investigation & $9.05 \%$ \\
\hline Others & $3.02 \%$ \\
\hline \multicolumn{2}{|l|}{ Number of travels last 3 years } \\
\hline$\leq 3$ times & $59.8 \%$ \\
\hline$\geq 4$ times & $40.2 \%$ \\
\hline \multicolumn{2}{|l|}{ Average length of stay during a visit } \\
\hline$\leq 4$ days & $73.1 \%$ \\
\hline$\geq 5$ days & $26.9 \%$ \\
\hline \multicolumn{2}{|l|}{ Sources of Information for choosing the place } \\
\hline Travel agencies & $6.4 \%$ \\
\hline Media & $25.8 \%$ \\
\hline Friends/relatives/business associates & $64.9 \%$ \\
\hline National tourist organizations & $2.90 \%$ \\
\hline
\end{tabular}

Moreover, respondents are also asked to rate the importance of given items that are supposed to be significant for the destination competitiveness of Bangladesh nature-based tourism. The importance of the items is measured on a five-point Likert scale where mid value is considered as 3. Any item with an average value lower than 3 is considered as less important when designing tourism services for prospective tourist. On the other hand, any item with an average value more than 3 and near to 5 would be more important in designing nature-based tourism services for the tourists. A constructive ranking of items on the basis of their average importance value are given below in table 2 with respective standard deviation. 
Table 2. Average importance value of destination attributes

\begin{tabular}{lcc}
\hline Observed Variables/attributes & Mean & Standard Deviation \\
\hline Personal safety and security of the place & 4.54 & 0.71 \\
Easy access to transportation services & 4.17 & 0.81 \\
Variety of natural attractions & 4.16 & 0.84 \\
Well-developed tourism markets and roads & 4.14 & 0.76 \\
Natural scenic beauty and calmness of the place & 4.14 & 0.78 \\
Well decorated and comfortable accommodations & 4.09 & 0.81 \\
Availability of healthcare and emergency medical treatments & 4.05 & 0.93 \\
Cleanness of the atmosphere & 3.94 & 0.84 \\
Reasonable price of different products & 3.93 & 0.88 \\
Quality of the overall tourism services & 3.88 & 0.75 \\
Pleasant climate and good environment & 3.88 & 0.93 \\
Availability of telecommunications with high speed internet and ATM & 3.86 & 0.93 \\
Reputation of the place & 3.76 & 0.87 \\
Access to information and easy communication with locals & 3.72 & 0.95 \\
Good quality and taste of foods and beverage & 3.64 & 0.88 \\
Variety of historical attraction and places & 3.64 & 0.95 \\
Availability of family oriented visited atmosphere & 3.56 & 2.22 \\
Shopping and entertainment facility & 3.52 & 1.04 \\
Friendliness and hospitality of the locals & 3.47 & 0.90 \\
Outdoor recreational facilities & 3.30 & 0.94 \\
Variety of cultural events and attractions & 3.26 & 1.01 \\
Availability of discounted tour packages & 3.22 & 1.06 \\
Similarity with the local lifestyle & 2.80 & 1.09 \\
Opportunity for visiting friends and relatives & 2.71 & 1.08 \\
\hline
\end{tabular}

Among the 24 items measured, 7 are considered as more important to respondent than others as all these has average importance value more than 4 out of 5 . The most important issue among all is personal safety and security of the place (4.54) followed by easy access to transportation services (4.17), variety of natural attractions (4.16), well-developed tourism markets and roads (4.14) and natural scenic beauty and calmness of the place (4.14). Besides two issues are considered less important as they find lowest mean value 2.71 for opportunity for visiting friends and relatives and 2.80 for similarity with the local lifestyle. All other items have a mean importance value between these 4.14 and 3.22 on scale of 5 .

In addition to this ranking of items, to find the drivers that the respondents consider important when they plan for nature-based tourism service, this study adopts an Exploratory Factor Analysis (EFA). As a statistical approach, factor analysis can be used to examine inter relationships among a large number of variables and to explain these variables in terms of their common underlying dimensions (factors) (Sultana, Siddique \& Islam, 2015). Therefore, to identify the underlying dimension of the nature-based tourism in Bangladesh a factor analysis with PROMAX rotation for 24 items or components is performed.

To ensure the data suitability for a EFA, all the variables are tested using both the Kaiser-Meyer-Olkin (KMO) measure of sampling adequacy (MSA) and Bartlett's test of sphericity (Bartlett, 1954). Results of these tests are presented in the table 3. The KMO measures the sampling adequacy which should be greater than 0.60 (Kaiser, 1970; Kaiser \& Rice, 1974) for a satisfactory factor analysis to proceed and if any pair of variables has a value less than this, one of them should be consider dropping from the analysis (Sultana, Siddique, \& Islam, 2015). In this study, the KMO score is 0.849 , which shows a very good score of sampling adequacy. Bartlett's test is another indication of the strength of the relationship among variables. From the table 3, it can be observed that the Bartlett's test of sphericity is statistically significant at 0.00 levels, i.e., its associated probability is less than 0.05 , which indicates that a PCA (principal component analysis) can be performed efficiently with the dataset. Hence, KMO and Bartlett's Test confirms that the dataset is perfect for factor analysis (Hair et al., 1998).

Table 3. Data suitability and sampling adequacy

\begin{tabular}{lll}
\hline Kaiser-Meyer-Olkin Measure of Sampling Adequacy & & 0.849 \\
\hline & Approx. Chi-Square & 2226.825 \\
Bartlett's Test of Sphericity & df & 276 \\
& Sig. & 0.000 \\
\hline
\end{tabular}


The factor analysis of the 24 components has yielded four factors explaining $42.62 \%$ of the total variance. Analyzing the factor loading, i.e., the correlation of each variable and the factor, can help in deriving a new construct. In this case, a loading was considered significant if it had an absolute value higher than 0.30 . In this study, as all the variables in the factor solution has at least one significant loading on a factor, most important factors can be derived. Based on the factor loading and Eigen values more than 1, four factors have been selected shown in the table 4 with their respective alpha value and variance level. The selection of the four factors is also supported by parallel analysis.

As the table 4 shows, the reliability coefficient range of Cronbach's alpha is from 0.763 (Factor 1) to 0.576 (Factor 4) indicating variables are internally consistent and a good correlation between retained factors and variables. Although $\alpha$ value of 0.70 and higher is often considered the criterion for internally consistent established factors (Hair et al., 1998), Nunnally (1978) suggests that $\alpha$ value of 0.50 and 0.60 is acceptable in the early stages of research. Since, Cronbach's $\alpha$ value for each factor is above 0.50 ; all four factors are accepted as being reliable for the research.

Factor 1 captures eight items of Tourism Infrastructure that accounted for $23.20 \%$ of total variance, namely easy access to transportation services, well developed tourism markets and roads, well decorated and comfortable accommodation, availability of healthcare and emergency medical treatments, shopping and entertainment facility, reasonable price of different products, Good quality and taste of foods and beverage, personal safety and security of the place. Factor 2 captured five items of Historical and Cultural Attractors that accounted for $7.80 \%$ of total variance namely variety of historical attraction and places, variety of cultural events and attractions, availability of discounted tour packages, friendliness and hospitality of the locals, quality of the overall tourism services.

In addition to these, factor 3 captured four items of Natural Attractors that accounted for $6.29 \%$ of total variance. It includes natural scenic beauty and calmness of the place, cleanness of the atmosphere, pleasant climate and good environment, variety of natural attractions. The last one, factor 4 captured four items of Communication Facilities and Lifestyle Similarities that explain 5.34\% of the total variance. It includes, Similarity with the local lifestyle, opportunity for visiting friends and relatives, access to information and easy communication with locals, availability of telecommunications with high speed internet and ATM. Other than these items, three items couldn't be put under any of the factors as they didn't produce any factor loading in pattern matrix (availability of family oriented visited atmosphere, reputation of the place, outdoor recreational facilities).

Table 4. Factor analysis and reliability testing results

\begin{tabular}{|c|c|c|}
\hline Factors & Loadings & Items \\
\hline \multicolumn{3}{|l|}{ Factor 1: Tourism Infrastructure } \\
\hline Percentage of Variance Explained $=23.20 \%$ & 0.714 & Easy access to transportation services \\
\hline Alpha $=0.763$ & 0.702 & Well-developed tourism markets and roads \\
\hline \multirow[t]{6}{*}{ Eigen Value $=5.568$} & 0.689 & Well decorated and comfortable accommodations \\
\hline & 0.585 & Availability of healthcare and emergency medical treatments \\
\hline & 0.375 & Shopping and entertainment facility \\
\hline & 0.341 & Reasonable price of different products \\
\hline & 0.331 & Good quality and taste of foods and beverage \\
\hline & 0.327 & Personal safety and security of the place \\
\hline \multicolumn{3}{|l|}{ Factor 2: Historical and Cultural Attractors } \\
\hline Percentage of Variance Explained $=7.80 \%$ & 0.773 & Variety of historical attraction and places \\
\hline Alpha $=0.649$ & 0.610 & Variety of cultural events and attractions \\
\hline \multirow[t]{3}{*}{ Eigen Value $=1.874$} & 0.426 & Availability of discounted tour packages \\
\hline & 0.379 & Friendliness and hospitality of the locals \\
\hline & 0.370 & Quality of the overall tourism services \\
\hline \multicolumn{3}{|l|}{ Factor 3: Natural Attractors } \\
\hline Percentage of Variance Explained $=6.29 \%$ & 0.765 & Natural scenic beauty and calmness of the place \\
\hline Alpha $=0.664$ & 0.638 & Cleanness of the atmosphere \\
\hline \multirow[t]{2}{*}{ Eigen Value $=1.508$} & 0.613 & Pleasant climate and good environment \\
\hline & 0.334 & Variety of natural attractions \\
\hline \multicolumn{3}{|c|}{ Factor 4: Communication facilities and lifestyle similarities } \\
\hline Percentage of Variance Explained $=5.34 \%$ & 0.606 & Similarity with the local lifestyle \\
\hline Alpha $=0.576$ & 0.547 & Opportunity for visiting friends and relatives \\
\hline \multirow[t]{2}{*}{ Eigen Value $=1.281$} & 0.330 & Access to information and easy communication with locals \\
\hline & 0.326 & Availability of telecommunications with high speed internet and ATM \\
\hline
\end{tabular}




\section{Conclusion}

To explore the current status of nature-based tourism of Bangladesh, this paper studies the demographics of the potential tourists; their perception about importance of different relevant tourism attributes in a rank of most to least importance; and identifies the most important factors for developing tourism competitiveness. By analyzing the demographic information, it has been observed that majority of the respondents are male (almost $3 / 4^{\text {th }}$ ) with an age structure 18 to 34 years (around 70\%). The major (more than $85 \%$ ) education qualification of the respondents is at least a higher secondary school certificate and above (bachelors/honors and masters). They usually are students in nature with almost equal participants from service sectors and business owners. Moreover, vacation/holiday, visiting friends/ relatives, and sightseeing are the major motivation of being a tourist. While in last three-year period, majority visits tourist place for at best three times or less, their average stay is maximum 4 days or less. Recommendation from the friends/relatives/business associates is the major source of information to the tourists.

Later on, the attributes related to nature-based tourism of Bangladesh are ranked on the basis of their importance to respondents from most to least. The ranking revealed that, among the 24 items measured, 7 are considered as more important to respondents than others as all these has average importance value more than 4 out of 5 . These seven more important attributes are from most importance to least- personal safety and security of the place; easy access to transportation services; variety of natural attractions; well-developed tourism markets and roads; natural scenic beauty and calmness of the place; well decorated and comfortable accommodations; and availability of healthcare and emergency medical treatments. Besides two issues are considered less important as they find lowest mean value- opportunity for visiting friends and relatives; and similarity with the local lifestyle. All other items have a good to average mean importance value ranged from 4.14 to 3.22 on scale of 5 .

Moreover, an Exploratory Factor Analysis (EFA) with PROMAX rotation shows that four factors are significantly important for nature-based tourism destination competitiveness of Bangladesh. These four factors are tourism Infrastructure; historical and cultural attractors; natural attractors; and communication facilities and lifestyle similarities which are extracted from selected 24 attributes. The findings also reveal that, along with natural, historical and cultural attractors, tourists are more concerned whether a particular destination is well equipped with tourism infrastructures, communication facilities and services or not. Initiatives from government level may concentrate on these factors when designing tourism policies for Bangladesh. Other than that, individual service providers within nature-based tourism of Bangladesh may facilitate better tourism infrastructure and ensure natural and cultural attractors in their service offerings.

Therefore, this study will contribute to the development of destination competitiveness of Bangladesh and fill up the gap of narrower concentration with tourism sector like, nature-based tourism. Thus, findings of the study enhance the strategic management initiatives and marketing and branding of Bangladeshi nature-based tourism to both inbound and international tourists. However, there are further scopes of the study in which an analysis can be made by matching tourists' perception of importance and performance of tourism attributes. Furthermore, such an analysis of getting ideas of important factors to nature-based tourism of Bangladesh can be drawn from the tourism service providers. Last but not the least; similar analysis can be adapted to other potential developing countries and/or specific sectors of the tourism services.

\section{References}

Ahmed, F., Azam, M. D. S., \& Bose, T. K. (2010). Factors Affecting the Selection of Tour Destination in Bangladesh: An Empirical Analysis. International Journal of Business and Management, 5(3), 52-61.

Ahmed, Z. U., \& Krohn, F. B. (1990). Reversing the United States' declining competitiveness in the marketing of international tourism: a perspective on future policy. Journal of Travel Research, 29(2), 23-29. https://doi.org/10.1177/004728759002900204

Akter, B., \& Hamid, A. (2013). Expectation versus Satisfaction Level of the Tourists of Sylhet Region. Bangladesh Research Publications Journal, 9(1), 15-21.

Alegre, J., \& Cladera, M. (2009). Analysing the effect of satisfaction and previous visits on tourist intentions to return. European Journal of Marketing, 43(5/6), 670-685. https://doi.org/10.1108/03090560910946990

Alhemoud, A. M., \& Armstrong, E. G. (1996). Image of Tourism Attractions in Kuwait. Journal of Travel Research, (34), 76. https://doi.org/10.1177/004728759603400413

Armenski, T., Dwyer, L., \& Pavluković, V. (2017). Destination Competitiveness: Public and Private Sector Tourism Management in Serbia. Journal of Travel Research (in press), 1-15. https://doi.org/10.1177/0047287517692445 
Bahar, O., \& Kozak, M. (2007). Advancing destination competitiveness research: comparison between tourists and service providers. Journal of Travel \& Tourism Marketing, 22(2), 61-71. https://doi.org/10.1300/J073v22n02_05

Balmford, A., Beresford, J., Green, J., Naidoo, R., Walpole, M., \& Manica, A. (2009). A Global Perspective on $\begin{array}{llllll}\text { Trends in Nature-Based Tourism. PLoS Biology } & \text { 7(6), } & \text { e000144. }\end{array}$ https://doi.org/10.1371/journal.pbio.1000144

Baloglu, S., \& McCleary, K. W. (1999). U.S. International Travelers: Images of Four Mediterranean Destinations: A Comparison of Visitors and Nonvisitors. Journal of Travel Research, 144-152. https://doi.org/10.1177/004728759903800207

Bartlett, M. S. (1954). A note on multiplying factors for various chi-squared approximations. Journal of the Royal Statistical Society, Series B, 16, 296-298.

Beerli, A., \& Martin J. D. (2004). Factors influencing destination image. Annals of Tourism Research, 31(3), 657-681. https://doi.org/10.1016/j.annals.2004.01.010

Bentler, P. M., \& Bonett, D. G. (1980). Significance tests and goodness of fit in the analysis of covariance structures. Psychological Bulletin, 88, 588-606. https://doi.org/10.1037/0033-2909.88.3.588

Berg, B. L. (2001). Qualitative research methods for the social sciences (4th ed.). Pearson Education Company.

Botha, C., Crompton, J. L., \& Kim, S. S. (1999). Developing a revised competitive position for Sun/Lost City, South Africa. Journal of Travel Research, 37, 341-352. https://doi.org/10.1177/004728759903700404

Bryman, A. (2001). Social Research Method. Oxford: Oxford University Press.

Ca-izares, S. S., \& Canalejo, A. M. C. (2015). A comparative study of tourist attitudes towards culinary tourism in Spain and Slovenia. British Food Journal, 117(9), 2387-2411. https://doi.org/10.1108/BFJ-01-2015-0008

Chen, P. J. (1999). International Students' Image of Rural Pennsylvania as a Travel Destination. Journal of Travel Research, 256-266. https://doi.org/10.1177/004728759903700307

Cohen, E., \& Avieli, N. (2004). Food in Tourism Attraction and Impediment. Annals of Tourism Research, 31(4), 755-778. https://doi.org/10.1016/j.annals.2004.02.003

Cracolici, M. F., \& Nijkamp, P. (2008). The attractiveness and competitiveness of tourist destinations: a study of Southern Italian regions. Tourism Management, 30, 336-344. https://doi.org/10.1016/j.tourman.2008.07.006

Creswell, J. W. (2008). Research Design: Qualitative, Quantitative, and Mixed Methods Approaches (3rd ed.). Thousand Oaks, California: SAGE Publications, Inc.

Croes, R. (2010). Measuring and explaining competitiveness in the context of small island destinations. Journal of Travel Research, 20(10), 1-12.

Croes, R., \& Kubickova, M. (2013). From potential to ability to compete: Towards a performance-based tourism competitiveness index. Journal of Destination Marketing \& Management, 2(3), 146-154. https://doi.org/10.1016/j.jdmm.2013.07.002

Crompton, J. L. (1979). An Assessment of the Image of Mexico as a Vacation Destination and the Influence of Geographical Location Upon That Image. Journal of Travel Research, 17, 18-23. https://doi.org/10.1177/004728757901700404

Crouch, G. I. (2011). Destination Competitiveness: An Analysis of Determinant Attributes. Journal of Travel Research, 50(1), 27-45. https://doi.org/10.1177/0047287510362776

Crouch, G. I., \& Ritchie, J. R. B. (1999). Tourism, competitiveness and societal prosperity. Journal of Business Research, 44(3), 137-152. https://doi.org/10.1016/S0148-2963(97)00196-3

Cucculelli, M., \& Goffi, G. (2015). Does sustainability enhance tourism destination competitiveness? Evidence from Italian Destinations of Excellence. Journal of Cleaner Production, 111(B), 370-382. http://dx.doi.org/10.1016/j.jclepro.2014.12.069

D'Harteserre, A. (2000). Lessons in managerial destination competitiveness in the case of foxwoods casino resort. Tourism Management, 21(1), 23-32. https://doi.org/10.1016/S0261-5177(99)00097-7

Dadgostar, B., \& Isotalo, R. M. (1992). Factors Affecting Time Spent by Near-Home Tourists in City Destinations. Journal of Travel Research, 34-39. https://doi.org/10.1177/004728759203100206

De Keyser, R., \& Vanhove, N. (1994). The competitive situation of tourism in the Caribbean area 
Methodological approach. Revue de Tourisme, 3, 19-22. https://doi.org/10.1108/eb058160

Dwyer, L., \& Kim, C. (2003). Destination competitiveness: determinants and indicators. Current Issues in Tourism, 6(5), 369-413. https://doi.org/10.1080/13683500308667962

Dwyer, L., Armenski T., Cvelbar L. K., Dragićević, V., \& Mihalic, T. (2015). Modified Importance-Performance Analysis for Evaluating Tourism Businesses Strategies: Comparison of Slovenia and Serbia. International Journal of Tourism Research, 18(4), 327-340. https://doi.org/10.1002/jtr.2052

Dwyer, L., Cvelbar, L. K., Edwards, D., \& Mihalic, T. (2012). Fashioning a destination tourism future: the case of Slovenia. Tourism Management, 33(2), 305-316. https://doi.org/10.1016/j.tourman.2011.03.010

Dwyer, L., Cvelbar, L. K., Mihalič, T., \& Koman, M. (2014). Integrated destination competitiveness model: testing its validity and data accessibility. Tourism Analysis, 19, 1-17. https://doi.org/10.3727/108354214X13927625340073

Dwyer, L., Edwards, D., Mistilis, N., Roman, C., \& Scott, N. (2009). Destination and enterprise management for a tourism future. Tourism Management, 30, 63-74. https://doi.org/10.1016/j.tourman.2008.04.002

Dwyer, L., Livaic, Z., \& Mellor, R. (2003). Competitiveness of Australia as a tourist destination. Journal of Hospitality and Tourism Management, 10(1), 60-78.

Dwyer, L., Mellor, R., Livaic, Z., Edwards, D., \& Kim, C. (2004). Attributes of Destination Competitiveness: A Factor Analysis. Tourism Analysis, 9(1-2), 91-101. https://doi.org/10.3727/1083542041437558

Easterby-Smith, M., Thorpe, R., \& Lowe, A. (1991). Management Research: An Introduction. London: Sage Publications.

Easterby-Smith, M., Thorpe, R., \& Lowe, A. (1999). Management Research: An Introduction. London: Sage Publication.

Enright, M. J., \& Newton, J. (2004). Tourism destination competitiveness: a quantitative approach. Tourism Management, 25, 777-788. https://doi.org/10.1016/j.tourman.2004.06.008

Enright, M. J., \& Newton, J. (2005). Determinants of Tourism Destination Competitiveness in Asia Pacific: Comprehensiveness and Universality. Journal of Travel Research, 43, 339-350. https://doi.org/10.1177/0047287505274647

Fakaye, P. C., \& Crompton, J. L. (1991). Image differences between prospective, first-time and repeat visitors to the lower Rio Grande valley. Journal of Travel Research, 30(2), 10-16. https://doi.org/10.1177/004728759103000202

Faulkner, B., Opperman, M., \& Fredline, E. (1999). Destination competitiveness: an exploratory examination of South Australia's core attractions. Journal of Vacation Marketing, 5(2), 125-139. https://doi.org/10.1177/135676679900500202

Gartner, A. D. (2007). Destination Image and Its Functional Relationships. Journal of Travel Research, 45(4), 413-425. https://doi.org/10.1177/0047287507299569

Gartner, W. C. (1993). Image formation process. Journal of Travel and Tourism Marketing, 2(2/3), 191, 215.

Gomezelj, D. O., \& Mihalic, T. (2008). Destination competitiveness-Applying different models, the case of Slovenia. Tourism Management, 29, 294-307. https://doi.org/10.1016/j.tourman.2007.03.009

Goodrich, J. (1978). A New Approach to Image Analysis through Multidimensional Scaling. Journal of Travel Research, 3-7. https://doi.org/10.1177/004728757801600302

Gooroochurn, N., \& Sugiyarto, G. (2005). Competitiveness indicators in the travel and tourism industry. Tourism Economics, 11(1), 25-43. https://doi.org/10.5367/0000000053297130

Haahti, A. J. (1986). Finland's competitive position as a destination. Annals of Tourism Research, 13, 11-35. https://doi.org/10.1016/0160-7383(86)90055-1

Haahti, A., \& Yavas, U. (1983). Tourists' perceptions of Finland and selected European countries as travel destinations. European Journal of Marketing, 17, 34-42. https://doi.org/10.1108/EUM0000000004833

Hair, J. F. Jr., Anderson, R. E., Tatham, R. L., \& Black, W. C. (1998). Multivariate Data Analysis (5th ed.). Upper Saddle River, NJ: Prentice Hall.

Hair, J. F., Black, W. C., Babin, B. J., \& Anderson, R. E. (2010). Multivariate Data Analysis (7th ed.). Prentice Hall, Upper Saddle River, New Jersey. 
Hall, C. M., \& Sharples, L. (2003). The consumption of experiences or the experience of consumption? An introduction to the tourism of taste. Food Tourism around the World: Development, Management and Markets, London, Butterworth-Heinemann.

Hanafiah, M. H., Hemdi, M. A., \& Ahmad, I. (2016). Does tourism destination competitiveness lead to performance? A case of ASEAN region. Tourism, 64(3), 251-260.

Hassan, S. S. (2000). Determinants of market competitiveness in an environmentally sustainable tourism industry. Journal of Travel Research, 38(3), 239-245. https://doi.org/10.1177/004728750003800305

Heath, E. (2003). Towards a model to enhance destination competitiveness: A Southern African perspective. Journal of Hospitality and Tourism Management, 10(2), 124-141.

Heung, V. C. S., Qu, H., \& Chu, R. (2001). The relationship between vacation factors and socio-demographic and travelling characteristics: the case of Japanese leisure travellers. Tourism Management, 22, 259-269. https://doi.org/10.1016/S0261-5177(00)00057-1

Hossain, M. D. E., Quaddus, M., \& Shanka, T. (2011). Factors effecting destination loyalty: a case of Cox's Bazar, Bangladesh, in 15th World Marketing Congress (WMC), Jul 19-23 2011, pp. 680-685.

Hossain, M. D. K., Siddique, P. K., \& Islam, S. (2015). Socio-Economic Analysis of Informal Business Activities: A Case Study on Central Business District Area of Dhaka City. Developing Country Studies, 5(7).

Hunt, J. D. (1975). Image as a Factor in Tourist Development. Journal of Travel Research, 1-17. https://doi.org/10.1177/004728757501300301

Kaiser, H. F. (1970). A second generation little jiffy. Psychometrika, 35, 401-415. https://doi.org/10.1007/BF02291817

Kaiser, H. F., \& Rice, J. (1974). Little Jiffy, Mark IV. Educational and Psychological Measurement, 34, 111-117. https://doi.org/10.1177/001316447403400115

Kaynak, E., \& Marandu, E. E. (2007). Tourism market potential analysis in Botswana: a Delphi study. Journal of Travel Research, 45, 227-237. https://doi.org/10.1177/0047287506291595

Kim, C., \& Dwyer, L. (2003). Destination Competitiveness and Bilateral Flows between Australia and Korea. Journal of Tourism Studies, 14(2), 54-67.

Kozak, M. (2002). Measuring comparative destination performance: a study in Spain and Turkey. Journal of Travel \& Tourism Marketing, 13(3), 83-110. https://doi.org/10.1300/J073v13n03_05

Kozak, M., \& Rimmington, M. (1999). Measuring tourist destination competitiveness: conceptual considerations and empirical findings. International Journal of Hospitality Management, 18(3), 273-283. https://doi.org/10.1016/S0278-4319(99)00034-1

Laarman, J. G., \& Gregersen, H. M. (1996). Pricing policy in nature-based tourism. Tourism Management, 17(4), 247-254. https://doi.org/10.1016/0261-5177(96)00016-7

Lee, C. F., \& King, B. (2009). A determination of destination competitiveness for Taiwan's Hot Springs tourism sector using the Delphi technique. Journal of Vacation Marketing, 15(3), 243-257. https://doi.org/10.1177/1356766709104270

Lee, Y. P., \& Chen, C. Y. (2010). Examining and comparing the competitiveness of tourism industry in Cambodia and Taiwan: an assessment from professionals. Journal of American Academy of Business, 16(1), 129-140.

Li, S., Kinman, R., Duan, Y., \& Edwards, J. S. (2000). Computer-based support for Marketing Strategy Development. European Journal of Marketing, 34, 551-575. https://doi.org/10.1108/03090560010321938

Madhavan, H., \& Rastogi, R. (2011). Social and psychological factors influencing destination preferences of domestic tourists in India. Leisure Studies, (2011), 1-11. http://dx.doi.org/10.1080/02614367.2011.632781

Mansfeld, Y. (1992). From motivation to actual marketing. Annals of Tourism Research, 19, 399-419. https://doi.org/10.1016/0160-7383(92)90127-B

Mazanec, J. A., Wober, K., \& Zins, A.H. (2007). Tourism destination competitiveness: from definition to explanation? Journal of Travel Research, 46(1), 86-95. https://doi.org/10.1177/0047287507302389

McIntosh, R., \& Goeldner, C. (1990). Tourism: Principles, Practices, Philosophies. New York: Wiley.

Mechinda, P., Serirat, S., Popaijit, N., Lertwannawit, A., \& Anuwichanont, J. (2010). The relative impact of 
competitiveness factors and destination equity on tourist's loyalty in Koh Chang, Thailand. International Business \& Economics Research Journal, 9(10), 99-114.

Merriam, S. B. (1988). Case Study Research in Education: A Qualitative Approach. San Francisco: Jossey-Bass Publishers.

Miller, M. M., Henthorne, T. L., \& George, B. P. (2008). The competitiveness of the Cuban tourism Industry in the twenty-first century: a strategic re-evaluation. Journal of Travel Research, 46(3), 268-278. https://doi.org/10.1177/0047287507308319

Milman, A., \& Pizam, A. (1995). The Role of Awareness and Familiarity with a Destination: The Central Florida Case. Journal of Travel Research, 21-27. https://doi.org/10.1177/004728759503300304

Minghetti, V., \& Montaguti, F. (2010). Assessing Istanbul competitiveness: a multidimensional approach. International Journal of Culture, Tourism and Hospitality Research, 4(3), 228-240. https://doi.org/10.1108/17506181011067619

Mohsin, A., \& Ryan, C. (2004). Determinants of Destination Choice: The Role of Socio-demographic Variables. Tourism Recreation Research, 29(3), 27-33. https://doi.org/10.1080/02508281.2004.11081454

Nunnally, J. C. (1978). Psychometric theory (2nd ed.). New York: McGraw-Hill.

Payne, S. L (1980). The art of asking questions. Princeton, N. J.: Princeton University Press https://doi.org/10.1515/9781400858064

Pestana, B., Laurent, B., Nicolas, P., Elisabeth, R., Bernardin, S., \& Assaf, A. (2011). Performance of French destination: tourism attraction perspectives. Tourism Management, 32, 141-146. https://doi.org/10.1016/j.tourman.2010.01.015

Pike, S. (2002). Destination Image Analysis: A Review of 142 Papers from 1973-2000. Tourism Management, 23(5), 541-549. https://doi.org/10.1016/S0261-5177(02)00005-5

Porter, M. E. (1990). The Competitive Advantage of Nations. New York: The Free Press. https://doi.org/10.1007/978-1-349-11336-1

Priskin, J. (2001). Assessment of natural resources for nature-based tourism: the case of the Central Coast Region of Western Australia. Tourism Management, 22, 637-648. https://doi.org/10.1016/S0261-5177(01)00039-5

Reaz, M. M. (2006). Corporate governance of banking institutions: a case study of Bangladesh. Thesis submitted to the University of Manchester for the degree of Doctor of Philosophy, In the Faculty of Humanities.

Ritchie, J. R. B., \& Crouch, G. I. (2000). The competitive destination, a sustainable perspective. Tourism Management, 2l(1), 1-7. https://doi.org/10.1079/9780851996646.0000

Ritchie, J. R. B., \& Crouch, G. I. (2003). The Competitive Destination: A Sustainable Tourism Perspective. Wallingford, UK: CABI. https://doi.org/10.1079/9780851996646.0000

Shih, D. (1986). VALS as A Tool of Tourism Market Research: The Pennsylvania Experience. Journal of Travel Research, 24(4), 2-11. https://doi.org/10.1177/004728758602400401

Sirse, J., \& Mihalic, T. (1999). Slovenian tourism and tourism policy e a case study. Revue de Tourisme, 3, 34-47. https://doi.org/10.1108/eb058313

Sonmez, S. (2002). A distorted destination image? The case of Turkey. Journal of Travel Research, 185-196. https://doi.org/10.1177/004728702237418

Sultana, M., Siddique, P. J., \& Islam, S. (2015). Factor Analysis of Consumer Behaviour in Jewellery Business: An Empirical Study on Bangladesh. European Journal of Business and Management, 7(5), 79-84.

Tisdell, C. A., \& Wilson, C. (2012). Natural-based tourism and conservation: new economic insights and case studies. Cheltenham: Edward Elgar. https://doi.org/10.4337/9781781005163

Um, S., \& Crompton, J. L. (1990). Attitude Determinants in Tourism Destination Choice. Annals of Tourism Research, 17(3), 432-48. https://doi.org/10.1016/0160-7383(90)90008-F

WEF. (2007). The Global competitiveness report 2007-2008: World Economic Forum. Geneva, Switzerland 2007.

Zhang, H., Gu, C., Gu, L., \& Zhang, Y. (2011). The evaluation of tourism destination competitiveness by topsis 
$\&$ information entropy. A case in the Yangtze river delta of China. Tourism Management, 32, $443-451$. https://doi.org/10.1016/j.tourman.2010.02.007

Zhang, J., \& Jensen, C. (2007). Comparative advantage: explaining tourism flows. Annals of Tourism Research, 34(1), 223-243. https://doi.org/10.1016/j.annals.2006.08.004

\section{Copyrights}

Copyright for this article is retained by the author, with first publication rights granted to the journal.

This is an open-access article distributed under the terms and conditions of the Creative Commons Attribution license (http://creativecommons.org/licenses/by/4.0/). 